\title{
Assessment of water-polluting sources by multivariate statistical methods in Putheri Lake, Kanyakumari, Tamil Nadu, India $\left[08^{\circ} 12^{\prime} 27.1^{\prime \prime} \mathrm{N} 77^{\circ} 25^{\prime} 54.7^{\prime \prime} \mathrm{E}\right]$
}

\author{
K. Esakkimuthu ${ }^{1}$ K. P. Vinod Kumar ${ }^{2} \cdot$ P. Ponram ${ }^{3}$
}

Received: 7 September 2015/Accepted: 21 September 2015/Published online: 5 October 2015

(C) Springer International Publishing 2015

\begin{abstract}
Physical, chemical and microbial content of Putheri Lake water were estimated. Principal component analysis and cluster analysis techniques are applied to the large water quality data sets for analyzing surface water contamination. This technique is useful to determine the correlation between water quality parameters and the identification of practical pollution indicators for delineating the domestic and agriculture pollution of the Putheri Lake. This work exposes agriculture runoff and domestic sewage as the main sources of pollution in Putheri Lake, thereby suggesting organic farming and centralized sewage treatment plant for controlling the same.
\end{abstract}

Keywords Organic pollutants - Inorganic pollutants · Multivariate analysis - Factor analysis

\section{Introduction}

Water is one of the most important natural resources for the survival of all living organisms. Lakes are usually reliable and consistent source of water for domestic, agricultural and industrial purposes. The quality and quantity of surface water in a lake is influenced by natural factors such as wind, rainfall, temperature and weathering of rocks. However, the physical and chemical attributes of water bodies are largely

K. P. Vinod Kumar

nanjilvino@ rediffmail.com

1 Department of Civil Engineering, SCAD Polytechnic College, Tirunelveli, India

2 Department of Chemistry, University College of Engineering, Nagercoil, India

3 R\&D, Tejas Translation Technologies, Nagercoil, India influenced by human activities. Substantial effects of pollution to water bodies also affect the biosphere around it (Gupta et al. 2005). Such a cause can be exponential in devastation and even leads to extinction of a number of floras and faunas. Putheri Lake lies in the coastal district of Kanyakumari, at the southernmost tip of Tamil Nadu state, India. Putheri Lake receives water from a canal outlet of Pechiparai Dam meant for irrigation. Much local agricultural runoff is also received by this lake. Putheri Lake is an important water body in this area. It partially fulfills drinking water needs of the locals, is used for irrigation and also helps to recharge the ground water aquifer. This lake was once an ecological hotspot and was home to several unique floras and faunas(Sridharan et al. 2011). Studies show that biodiversity around and in this lake have been depleted over decades (Jenila and Radha Krishnan Nair 2012). Assimilation of industrial wastes, huge quantities of agriculture runoff and residential sewages are the primary polluting sources in this lake (Jain et al. 1999).

To date, no studies have been recorded to analyze and estimate the quantity of pollution and sources of pollution here. To better protect the ecological reserve and this water body, the current study was undertaken to assess the water quality of Putheri Lake.

This study emphasizes the significance of water pollution monitoring and provides a useful tool that could help the decision makers in determining the extent of pollution via practical pollution indicators.

\section{Study area}

Kanyakumari district includes a land area of $1684 \mathrm{~km}^{2}$ and occupies 1.295 percentage of the total area of the Tamil Nadu state in India. This district lies between $770-15^{\prime}$ and 


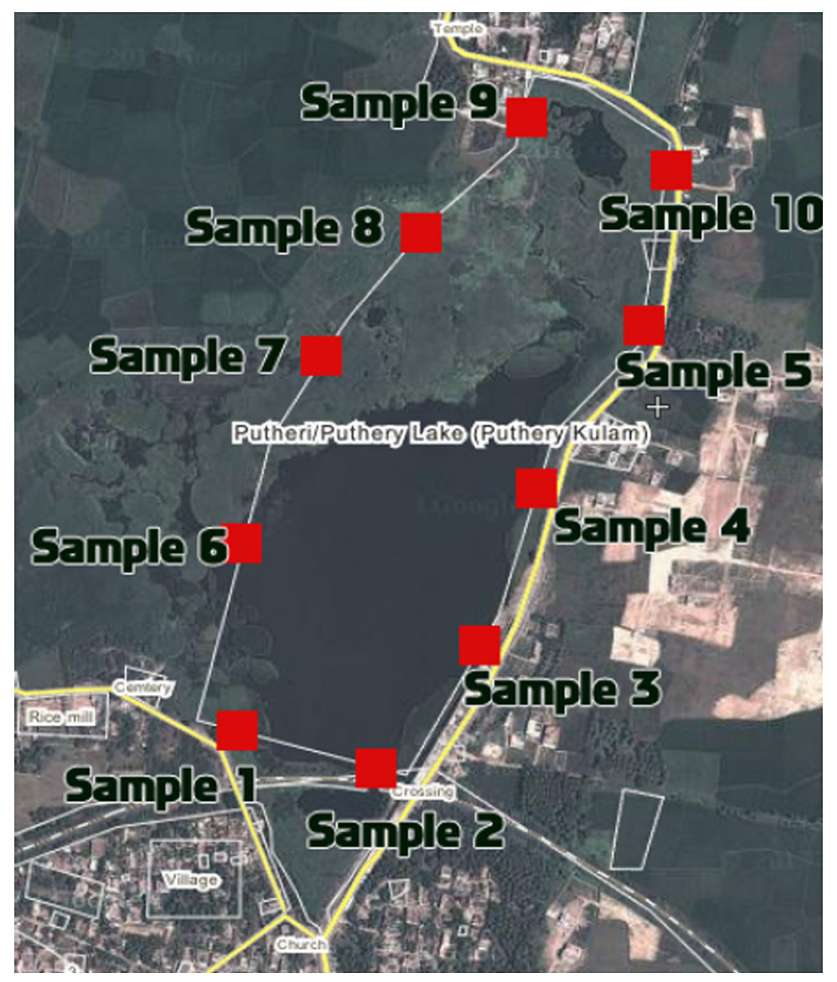

Fig. 1 Putheri Lake and site of sample collection

$770-36^{\prime}$ of the eastern longitude and $80-35^{\prime}$ and $80-35^{\prime}$ of the northern latitude. Kanyakumari district enjoys a warm climate. The first southwest monsoon is from June to September, while the second one comes from the northeast from October to December. These two seasons provide abundant water to this district. The annual rainfall ranges between 90 and $160 \mathrm{~cm}$.

The present works deal with the analysis of water quality taken from Putheri Lake. Location of the lake and key sampling points are shown in Fig. $1\left(08^{\circ} 12^{\prime} 27.1^{\prime \prime} \mathrm{N}\right.$ $\left.77^{\circ} 25^{\prime} 54.7^{\prime \prime} \mathrm{E}\right)$.

\section{Methods}

Ten water samples were collected from south to north of the Putheri Lake as per the sampling procedure shown in the map. The water samples were collected in 2-1 sealed containers and brought to the laboratory within $6 \mathrm{~h}$ of collection. Care was taken to guard the samples against shaking and exposure to the atmosphere during transport. Physical, chemical and biological analyses including Turbidity, EC(electrical conductivity), TDS(total dissolved solids), $\mathrm{pH}$, Alk(alkalinity), TH(total hardness), $\mathrm{Ca}, \mathrm{Mg}, \mathrm{Na}, \mathrm{K}, \mathrm{Fe}, \mathrm{Mn}, \mathrm{Cl}, \mathrm{F}, \mathrm{NH}_{3}, \mathrm{NO}_{2}, \mathrm{NO}_{3}, \mathrm{BOD}$ and DO were obtained from the water samples collected from the lake.

\section{Multivariate statistical analysis}

\section{Principal components analysis (PCA)}

PCA involves correlated variables for decreasing the variables quantity, thereby maintaining the same quantity of variance with some variables (Boyacioglu 2006). Factor analysis provides correlations between the observations with fundamental factors (Yu et al. 2003). PCA differs from FA in that the former takes all variance as common (Wulder 2007).

\section{Cluster analysis (CA)}

Significant and effective combinations that can provide voluminous information were developed with cluster analysis (Boyacioglu and Boyacioglu 2007). This technique uses huge interdependent variables for this purpose (McGarial et al. 2000). CA splits a huge number of objects into small homogenous groups based on their correlation structure (DeCoster 1998).

A significant feature of cluster analysis is that observations are grouped into certain distinct classes which provide similarity maximized inside the group and minimized among groups (Zeng and Rasmussen 2005). Also, it analyses the relations within a single set of variables (McGarial et al. 2000). Default clustering comprises observation of similarity defining, grouping and data abstraction (Mihailov et al. 2005).

This work includes the usage of "multivariate statistical techniques" to surface water quality data sets recorded from Putheri Lake. Statistical calculations were performed using the "Multivariate Statistical Package (MVSP) for Windows'. In this work, multivariate statistical techniques such as factor, principal component, and cluster analysis were applied to the large amounts of data recorded from the ten monitoring points of Putheri Lake.

\section{Results and discussion}

The results of the water tests are given in Table 1.

\section{Principal components analysis (PCA)}

One of the most important steps of factor analysis (Manly 1994) is to determine the number of factor that needs to be extracted for an accurate analysis of the data. In this regard, the rotation of the factor axis is executed to yield a "simple structure" such that factors that are somehow clearly marked by high loading for some variables and low loading for others, facilitating data interpretation in terms of original variables (Lewis-Beck 1994). 
Table 1 Physical, chemical and bacteriological examination results for water samples

\begin{tabular}{|c|c|c|c|c|c|c|c|c|c|c|}
\hline & Sample 1 & Sample 2 & Sample 3 & Sample 4 & Sample 5 & Sample 6 & Sample 7 & Sample 8 & Sample 9 & Sample 10 \\
\hline Turbidity & 12 & 12.7 & 13.5 & 14.5 & 16 & 18 & 17 & 16 & 15 & 14 \\
\hline TDS & 253 & 253 & 254 & 255 & 255 & 284 & 273 & 279 & 265 & 262 \\
\hline $\mathrm{EC}$ & 383 & 385 & 384 & 383 & 387 & 431 & 429 & 418 & 404 & 397 \\
\hline $\mathrm{pF}$ & 7.39 & 7.42 & 7.45 & 7.47 & 7.49 & 7.46 & 7.48 & 7.49 & 7.5 & 7.51 \\
\hline Alkalinity & 112 & 114 & 113 & 115 & 116 & 116 & 118 & 120 & 122 & 124 \\
\hline $\mathrm{TH}$ & 100 & 103 & 109 & 114 & 116 & 120 & 118 & 113 & 109 & 108 \\
\hline $\mathrm{Ca}$ & 24 & 22 & 23 & 21 & 22 & 34 & 33 & 31 & 32 & 30 \\
\hline $\mathrm{Mg}$ & 10 & 11 & 13 & 12 & 14 & 9 & 7 & 8 & 8 & 8 \\
\hline $\mathrm{Na}$ & 33 & 33 & 34 & 33 & 34 & 38 & 37 & 36 & 37 & 37 \\
\hline $\mathrm{K}$ & 6 & 6 & 6 & 6 & 6 & 7 & 7 & 7 & 5 & 5 \\
\hline $\mathrm{Fe}$ & 1.18 & 1.28 & 1.32 & 1.47 & 1.53 & 1.65 & 1.6 & 1.54 & 1.4 & 1.41 \\
\hline $\mathrm{Mn}$ & 0.17 & 0.17 & 0.17 & 0.17 & 0.17 & 0.17 & 0.17 & 0.17 & 0.17 & 0.17 \\
\hline NH3 & 0.35 & 0.36 & 0.38 & 0.37 & 0.38 & 0.62 & 0.69 & 0.72 & 0.87 & 0.92 \\
\hline $\mathrm{NO} 2$ & 0.24 & 0.22 & 0.2 & 0.19 & 0.18 & 0.16 & 0.14 & 0.12 & 0.13 & 0.12 \\
\hline NO3 & 2 & 2 & 3 & 2 & 3 & 2 & 2 & 3 & 2 & 2 \\
\hline $\mathrm{Cl}$ & 56 & 55 & 54 & 53 & 52 & 62 & 60 & 55 & 42 & 44 \\
\hline $\mathrm{F}$ & 0.2 & 0.2 & 0.1 & 0.1 & 0 & 0 & 0 & 0 & 0 & 0 \\
\hline $\mathrm{SO} 4$ & 14 & 14 & 13 & 12 & 13 & 14 & 12 & 13 & 10 & 9 \\
\hline PO4 & 0.45 & 0.52 & 0.65 & 0.7 & 0.8 & 0.9 & 0.94 & 0.97 & 1 & 1.05 \\
\hline DO & 6 & 6.2 & 6.4 & 6.6 & 6.7 & 3.9 & 3.8 & 4.2 & 4.5 & 4.9 \\
\hline BOD & 14 & 16 & 14 & 12 & 12 & 9 & 11 & 13 & 14 & 15 \\
\hline Coliform & 480 & 427 & 378 & 340 & 310 & 370 & 340 & 319 & 296 & 280 \\
\hline
\end{tabular}

Table 2 Eigenvalues, percent of variance, and cumulative percent of variance

\begin{tabular}{lccc}
\hline Factor & Eigenvalues & $\begin{array}{l}\text { Percent of } \\
\text { variance }\end{array}$ & $\begin{array}{l}\text { Cumulative percent } \\
\text { of variance }\end{array}$ \\
\hline 1 & 617.833 & 99.545 & 99.545 \\
2 & 1.533 & 0.247 & 99.792 \\
3 & 0.921 & 0.148 & 99.941 \\
4 & 0.364 & 0.059 & 99.999 \\
5 & 0.005 & 0.001 & 100.000 \\
\hline
\end{tabular}

To determine the number of factors to be used, the variances and co-variances of the variance are computed and given in Table 2. Then, the eigenvalues and eigenvector are evaluated for the covariance matrix and the data are transformed into factors. The eigenvalues and percentages of variance are associated with each factor. These values are also summed to express as a cumulative eigenvalue and percentage of variance.

In 1958, Kaiser proposed to use only the factor with eigenvalues exceeding one (Liu et al. 2003). Parallel to his proposal, two factors explaining $99.792 \%$ of the total variance are retained in this particular study.

Then, the Kaiser varimax rotation scheme is implemented to evaluate factor loading that correlates the
Table 3 Loading for various rotated factor matrix of twofactor model explaining $99.792 \%$ of the total variance

\begin{tabular}{llr}
\hline Variable & Factor 1 & Factor 2 \\
\hline EC & 0.876 & -0.299 \\
BOD & 0.245 & 0.589 \\
Ca & 0.223 & 0.317 \\
Turbidity & 0.333 & -0.078 \\
NH3 & 0.108 & 0.677 \\
\hline
\end{tabular}

factor and the variables. The rotated factor matrix of the two-factor model is created. The factor loading is used to group the water quality parameters and represents the most important information for interpreting the data. Quality variables calculated for factor 1 and factor 2 was shown in Table 3.

The next step of the analysis is to compute the contribution of each factor at every site giving the factor scores. The factor scores are projections of data onto corresponding eigenvector. They could be considered as the actual values of station on the underlying factors. The factor scores were calculated for all 10 monitoring stations as shown in Table 4.

The eigenvalues, the percentage of variance, and the cumulative percentage of variance are presented in Table 2. It reveals that first two factors explain 
Table 4 Score for the twofactor model

\begin{tabular}{llr}
\hline Station no & Factor 1 & Factor 2 \\
\hline 1 & 7.236 & -0.419 \\
2 & 7.321 & -0.371 \\
3 & 7.410 & -0.239 \\
4 & 7.464 & -0.201 \\
5 & 7.627 & -0.212 \\
6 & 8.494 & -0.275 \\
7 & 8.484 & -0.006 \\
8 & 8.318 & 0.249 \\
9 & 8.127 & 0.602 \\
10 & 7.983 & 0.759 \\
\hline
\end{tabular}

approximately $99.792 \%$ of total variance. This value corresponds to a relatively high representation of the variables by the two-factor model.

Factor 1 explains $99.545 \%$ of the total variance (Table 2). It is clearly seen from Table that factor has strong positive loading for electrical conductivity which corresponds to sulfate, sodium, calcium, nitrogen oxides, and other anions and cations. These high loadings represent a relative high correlation between each other. This finding reflects a negative influence on surface water quality by agriculture and other discharges hence could be considered as "inorganic contamination".

Factor 2 explains the 0.247 (Eigen value exceeding 1) of the total variance (Table 2) with strong absolute loadings on biochemical oxygen demand and total coliform. The relationship between these variables reflects the significance of domestic waste discharges and could be identified as "Organic contamination". The high scores for Factor 1 are observed at all 10 stations indicating inorganic pollution risk. Similarly, the high scores for Factor 2 are observed at stations 8, 9 and 10 and are representative of organic contamination agreeing with organic waste discharge.

The findings discussed above reveal the fact that any water quality parameter represented by Factor 1 and 2 could be used as an indicator for potential contamination of inorganic and organic matter, respectively. In other words, any arbitrarily selected parameter from Factors 1 and 2 could be used as a "marker" variable to detect potential contamination. Probable candidates for this purpose could be any one of the easily measured parameters such as electrical conductivity for Factor 1 and biological oxygen demand for Factor 2.

\section{Cluster analysis (CA)}

The dendrogram of the observed locations dataset as shown in Fig. 2 was generated using Euclidean distance of HCA for $\mathrm{CA}$ result. Based on Euclidean distance, two major clustering groups (Cluster 1 and Cluster 2) were observed.

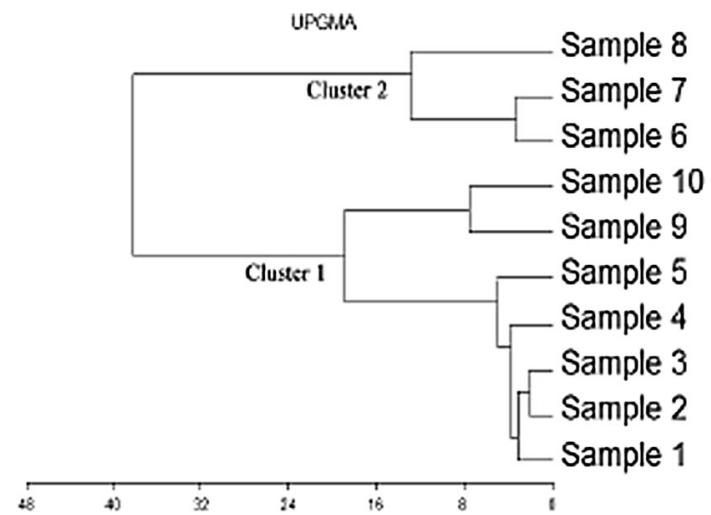

Fig. 2 Dendrogram of hierarchical cluster analysis

Cluster 1 characterized with low Euclidean distance corresponds to 7 locations (1, 2, 3, 4, 5, 9 and 10). Cluster 2 which has high Euclidean distance is coherent to 3 locations (6, 7 and 8). Subgroup clusters were also clarified within the major Cluster 1 and vary with significance Euclidean distance. The dendrogram clarifies Cluster 1 as the abnormality observation which had high variation in the concentration of the surface water quality parameters compared to Cluster 2. The variation in Cluster 1 might be due to lower polluted effluents from non-point sources (agricultural and urban activities). Cluster 2 shows a high pollution from the agricultural area which encompasses the springs.

\section{Conclusion}

The southern and northern parts of Putheri Lake are occupied by residential areas. The western part receives agricultural runoff from the paddy fields. The results of the analysis vindicates this finding because the bank near the residential area is polluted relatively more by organic pollutants and the other zone by inorganic pollutants. Principal component analysis (PCA) and cluster analysis (CA) techniques are implemented to analyze large water quality data sets obtained from monitoring station at various locations within Putheri Lake. Two factors are found to be significant in representing the water quality parameters recorded in the basin. These factors are believed to represent organic and inorganic contamination due to domestic and agricultural pollution. A marker parameter from each one of these groups could be used as an indicator for potential contamination in the basin. To help alleviate the current situation, organic contaminants from households could be treated by centralized sewage treatment plants. The inorganic pollutants from agriculture fields could be mitigated by encouraging the farmer community to use organic farming methods such as using natural fertilizers 
and pesticides. The current assessment also provides a rough guideline for selecting the priorities of possible prevention measures in the proper management of this important body of surface water.

\section{References}

Boyacioglu H (2006) Development of universal water quality index and environmetric analysis in surface water quality assessment with field implementation and validation. Karlsruhe University. Master of science thesis supervised by Prof. Dr. Franz Nestmann (2006)

Boyacioglu H, Boyacioglu H (2007) Surface water quality assessment by environmetric methods. Environ Monit Assess (in press)

DeCoster J (1998) Overview of factor analysis. http://www.stat-help. com/notes.html. Retrieved May 242006

Gupta AK, Gupta SK, Patil RS (2005) Statistical analyses of coastal water quality for a port and harbour region in India. Environ Monit Assess 102:179-200

Jain AK, Murty MN, Flynn PJ (1999) Data clustering: a review. ACM computing surveys, vol. 31, no. 3. http://kilana.unibe.ch:8080/ SCG/uploads/596/p264-jain.pdf. Retrieved May 262006

Jenila GJ, Radha Krishnan Nair C (2012) Biodiversity of bacterial pollutants in lentic ecosystems of Kanyakumari district, Tamilnadu. J Basic Appl Biol 6(3\&4):31-35

Lewis-Beck MS (1994) Factor analysis and related techniques. Sae and Toppan Publications, USA

Liu C, Lin K, Kuo Y (2003) Application of factor analysis in the environment of groundwater quality in a blackfoot disease area in Taiwan. Sci Total Environ 313:77-89
Manly BFJ (1994) Multivariate statical methods. Chapman and Hall, New York

McGarial K, Cushman S, Stafford S (2000) Multivariate statistics for wildlife and ecologyresearch. Springer, New York

Mihailov G, Simeonov V, Nikolov N, Mirinchev G (2005) Multivariate statistical assessment of the pollution sources along the stream of Kamchia River, Bulgaria. Water Sci Technol 51(11):37-43

Praus P (2005) Water quality assessment using SVD-based principal component analysis of hydrological data. Water SA 31:417-422

Simeonov V, Stratis J, Samara C, Zachariadis G, Voutsa D, Anthemidis A, Sofoniou M, Kouimtzis T (2003) Assessment of the surface water quality in Northern Greece. Water Res $37: 4119-4124$

Spanos T, Simeonov V, Stratis J, Xristina X (2003) Assessment of water quality for human consumption. Microchim Acta 141:35-40

Sridharan N et al (2011) Status of wetland birds in Kanyakumari, Thanjavur, Cuddalore and Nagapattinam Districts of Tamil Nadu, India. Indian For 137(10):1177-1182

Suhr D (2005) Principal component analysis vs. exploratory factor analysis.SUGI 30 proceedings. http://www2.sas.com/proceed ings/sugi30/Leadrs30.pdf. Retrieved Jan 30

Wulder M (2007) A practical guide to the use of selected multivariate statistics. http://www.pfc.cfs.nrcan.gc.ca/profiles/wulder/mvstats/ index_e.html. Retrieved Feb 52007

Yu S, Shang J, Zhao J, Guo H (2003) Factor analysis and dynamics of water quality of the Songhua River Northeast China. Water Air Soil Pollut 144:159-169

Zeng X, Rasmussen TC (2005) Multivariate statistical characterization of water quality in Lake Lanier, Georgia, USA. J Environ Qual 34:1980-1991 